\title{
Feminist Discourse In The Muslim Societies
}

\author{
Riffat Haque \\ Department of Women's Studies \\ Allama Iqbal Open University, Islamabad
}

\begin{abstract}
The present commentary is an attempt to trace the history of feminism in the Muslims countries and see how far the western feminist frameworks has influenced or provided impetus to the benchmarks, debates and struggles.

Women rights agenda any where in the world can not be decontextualized from its history, politics, economy, customs, religion, traditions and geographical location. In the Muslim countries the discourse of women activism against the societal oppression and exploitation has been linked with colonization and state power as well as. Any Study of feminism shows that its meaning changes overtime and place and therefore, diverse nature of feminism in Muslim countries.

Muslim women in pursuit of their rights have distanced themselves from many aspects of western feminism. They have faced fieree opposition within their societies. As in Muslim societies feminist agendas are considered as a challenge to Islam and Islamic culture. As elaborated in the article it is seen there is not one "Islamic" position in cultural practices and the contradictory practices are the issue not the Sharia Laws in itself. The women rights agenda are not against Islam rather unIslamic practices in the societies such as basic rights to health, education, property rights, polygamy, marital status etc.
\end{abstract}

\section{تخخيص المقالم}

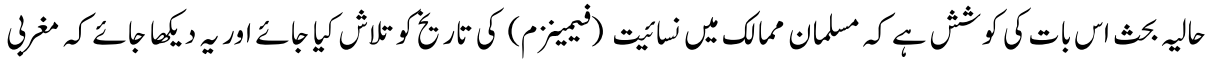

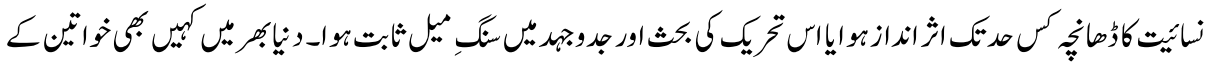

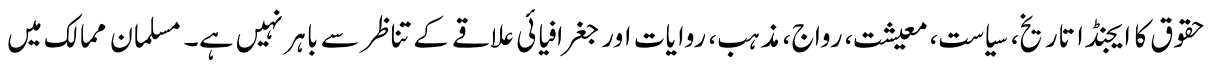

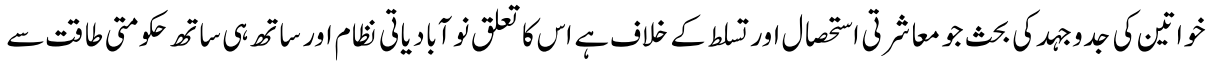

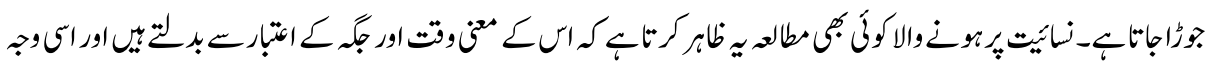

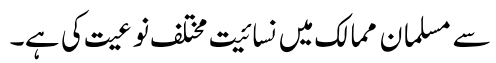

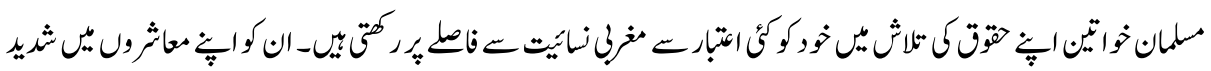

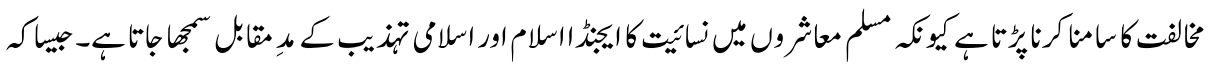

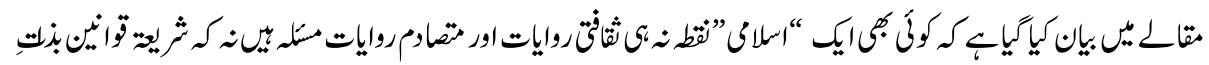

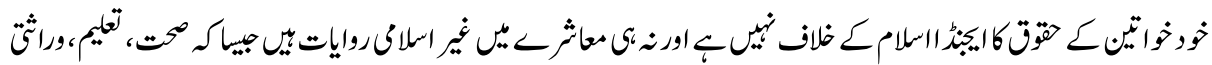

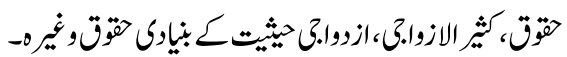




\section{Introduction}

Whether Eastern or Western, basically all feminist pursuits are aimed at social movement, acquiring rights for women from the society to which they belong. Feminists dare to break the conspiracy of silence about the oppressive, unequal relationship between men and women, and who want to change it (Tuttle 1987: 107-8). Throughout known history male domination has been pervasive, particularly within patriarchal social structures, including political and economic arenas (Mies 1986). The agenda of feminism encompasses many dimensions, including an analysis of gender roles, patriarchy, class struggle, national liberation, poverty and development, dowry killing, violence against women and the nature of religious exploitation. Regardless, the analysis of any feminism cannot be de-contextualized from its background, religion, history, politics, economy, customs, traditions and geographical location.

Any historical study of feminism shows that the meaning of feminism has changed over time and from place to place, and is often disputed (Moghadam 2002b: 12). In any context concrete experience and change in any given place ratify the definition of feminism over time (Badran 1995). Thus, for example, over recent decades women of different ethnicities have gradually dismantled monolithic views that placed the family as the sole site of oppression, or which regarded employment as the path to liberation, and envisaged patriarchy as an uncomplicated singular force (Afshar and Maynard 2000).

\section{How feminism is perceived in the Muslim countries}

In Muslim countries women who have chosen the discourse of activism against the prevalent oppression and exploitation of an unequal society are often declared to be 'sinful'. Both religious and political leaders issue decrees to suppress acts of gross feminist defiance, labeling them un-Islamic and westernized. Therefore, articulation of any feminist discourse co-exists, albeit uneasily. The term 'feminism' brings with it pejorative attitudes, so much so that Western feminism ${ }^{1}$ is perceived synonymously with colonialism and Western capitalism. In the early 1970's when third world women quite hesitantly adopted the term 'feminism', there was a lot of criticism from within their own countries and from outside as well. For feminists who were trying to be effective within their cultures of origin, these criticisms often had a debilitating impact (Okin 2000). In pursuit of their rights they had to walk a fine line trying to maintain a clear separation from many aspects of Western feminism, yet they still sometimes faced fierce opposition from within Islamic culture. The global hegemony of Western scholarship has had political effects and implications for Muslim women (Maumoon 1999: 280). Initially Muslim women were concerned with destroying myths about Islam propagated by earlier Western feminists, and their accusations regarding the subordination of Muslim women. Thus, initially, third world women disassociated themselves from any kind of Western 
feminism (Mies 1986). The domination of Western feminism meant that the range of women's issues considered was narrowly and parochially conceived.

Furthermore, feminism was slow to be adopted by women in Asia, the Middle East, Africa and Latin America because there have been other pressing issues to deal with such as national liberation, issues of poverty and development, class and creed. Women's liberation and questions of identity as expressed by Western feminists were positioned as secondary to these other struggles (Afshar and Maynard 2000). However, the Western paradigm of feminism does provide one useful framework for understanding the debate concerning feminism in the Muslim world for example; as Moghissi suggests that if feminism is a political and intellectual ideology advocating women's rights then feminism has always been crucial to Islamic societies (1999: 126). Despite this, women of different ethnicities have had an uphill struggle to redefine Western feminist terms, benchmarks and understandings in ways that are germane for their own societies (Afshar and Maynard 2000).

The French term 'feminisme' was coined in 1880s but was not widely used until the end of century when 'feminism' was used in England and later in 1910 it appeared in the United States. Just a decade later 'Nisa'I' began to be used to signify 'feminist' in Egypt (Badran 1995: 19). In the Arab world, from a literary and historical point of view, the term 'feminism' first appeared in 1909 when Malak Hifni Nasif published a collection of articles and speeches in a book entitled Al-Nisaiyat (meaning something by or about women). Politically, in 1923, Egyptian women first used the term 'feminist' to define themselves and their organization 'al-Ittihad al-Nisa'i al-Misri' (the Egyptian Feminist Union). Another historian of feminism, Karen Offen (quoted in Badran 2002: 1), suggests that initially the term 'Islamic feminism' was used in the 1990's in Turkey by Nilufer Gole in her edited book The Forbidden Modren (published in Turkish in 1991 and in English in 1996), and in articles by Yesim Arat and Feride Ajar. The South African activist, Shamim Shaikh, applied feminism to Islam, again providing in her writings and speeches evidence of the term being embraced by Muslims. Other terms in Arabic like unthawiyat (womanists) and nassawiyat (remakers of women) represent the educated, privileged, and engaged women who are struggling to improve the situation of women. Thus these terms are synonymous with, and arguably serve the same function as, 'feminism'.

\section{Origins of Feminism in Muslim society}

The expanding literature of Muslim societies published in the last two decades in the Middle East, Asia and Africa (Ahmed 1992; Tucker 1993; Moghadam 1994a, 1994b; Moghissi 1999; Poya 1999; Cooke 2001; Roded 2001) suggests that arguably, the 'project' of feminism in Muslim countries has a grounding in indigenous politics, culture, class and religion and did not originate solely from the influence of feminism in the West. 
For example, the history of the Arabs ${ }^{2}$ from pre-Islamic times to the early stages of Islam provides instances of women who exercised a high degree of authority and independence. Examples are, Khadija (a business-woman), Aishia (who fought wars and is the most authentic transmitter of the Hadith), and other wives of the Holy Prophet (Saadawi 1980; Mernissi 1987). But, in the early stages of Islam, pre-existing eastern Mediterranean practices restricting the freedoms of women were assimilated within Islamic societies. This makes it difficult to assess the role of Islam in restricting the rights of women (Majid 1998: 6; Ahmed 1992: 63). According to Ahmed, the rapid acquisition of vast foreign territories (Greco-Roman, Byzantine, Mesopotamian and Mediterranean Europe) led to Arab and non-Arab prejudices against women being incorporated into Islamic Law from a number of religious and cultural traditions, including the Judaic, Christian and Iranian (1992: 238). Successive Islamic rulers and kings subsequently legalized restrictive practices to stop women's active participation in socioeconomic life.

The adoption of misogynist attitudes occurred despite existing cultural practices to the contrary. For example, historical records show large numbers of women attending the mosque in Shiraz. Also, the respect and dignity shown to Turkish women impressed the Moroccan traveler and writer Ibn Battuta (reference from H. R.A. Gibb (1325-1354) in Minai 1981: 43). Similarly Muslim women in Islamic Spain of the eleventh and twelfth centuries provide evidence of extravagant expression in their poems and life styles. These examples indicate that Islam itself was not inherently and universally oppressive of women.

\section{Period from 1860s to early 1920s}

Western travel accounts of this period (such as of Lady Mary Wortley Montaqu's portrayal of Turkey in the eighteenth century), mention the liberty enjoyed by women in Muslim societies. She stated that she could not compare it with any other country (quoted in Majid, from Melman 1992: 87; Minai 1981: 43-61). Similarly, in her ethnographic study of women in the Middle East and Turkey, Women of Turkey and Their Folklore (1893), Mary Lucy Garnet praised Muslim women for their superiority in social life, hygiene, economics and legal rights. The harem ${ }^{3}$ did not prevent Egyptian women from conducting business and international trade while still living within Islamic conventions prior to the influence from the West. Women exercised sufficient control over their lives to go to the courts for divorce, for business deals, and for unpaid loans, exactly as men did.

Furthermore, Ahmed (1992: 145) provides evidence of attempts in the 1870s and 1880s by Muslim intellectuals in Egypt, such as al-Tahtawi and Abdu, to reform matters such as polygamy, divorce and education. Later, in the 1890s, Qasim Amin (1992) put forward a thesis on social transformation in his book, The Liberation of Women, stressing women's rights to education and the need for the reinterpretation and reform of Islam in order to 
limit or prohibit practices such as polygamy, seclusion, and hijab in order to create a more civilized society. In examining the literature by Middle Eastern women in the late nineteenth and especially in the early twentieth centuries one finds many of the women authors were either educated by European teachers or were privileged to be educated in Europe or one of their parents was European (Badran and Cooke 1990; Minai 1981). Thus their feminist thinking had some inspiration from the West although it was grounded in their own indigenous issues and culture.

Marsot suggests that once the trade routes of the powerful Muslim Ottoman Empire (1281-1924) were reoriented towards Europe, Muslim women's economic independence was eroded (1996a: 41-44). Women's role as producers of goods was minimized and more importantly, women's work was not judged in monetary terms or considered to be economically productive. Due to the introduction of technology and the increase of manufacturing, retail work, and the commercialization of agriculture, women's trade and casual work of other kinds was marginalized (Marsot 1996a; Petry 1992; Quataert 1992). For the period from 1800-1914, Tucker (1985) has traced at length the impact of economic, political, social transformation and colonialism on women, as during this time institutions were controlled by foreigners and ideologies alien to local customs. Likewise, in this period of economic dislocation, defense of the traditional family structure spelled security for many women. Women's status was accordingly affected and as their dependence on men increased, so did their marginalization. The colonizers' adoption of a 'civilizing mission' and 'colonial feminism' that imposed liberating policies in areas of women's rights inevitably further aggravated the Muslim male (Ahmed 1992) which led to a backlash. Thus, the 'hiding' of women's bodies from the gaze of the Western viewer and the protection of their minds from modernization, symbolized protection of the Islamic identity, communal dignity and social and cultural continuity (Moghissi 1999; Hoodfar 1993).

In the late nineteenth century lone voices of individual women and men expressed their resentment against the oppressive domination of males in their writings and demanded the fair treatment of women (Badran and Cooke 1990; Mojab 2001). In the Islamic World, feminist ideas had been evidenced in these individual efforts but collective, organized action or social movements were inconspicuous or invisible until the beginning of the twentieth century (Baden 1992; Badran and Cooke 1990).

\section{Colonialism, Nationalism and Feminism from 1920s to 1960s}

According to Badran (1995: 21) the efforts of a select number of women from 1920-1960 in Muslim countries were 'feminist' on the basis of their ideas, agendas and actions, although the women themselves did not explicitly adopt this identity. At much the same time as the first wave of feminism in Western countries, by the end of World War I Muslim women's voices, (a visible feminism) were included in public discourse through 
their participation in national liberation struggles, especially in Turkey, Iran, Egypt, Syria, Algeria, Morocco and South Asia. By the middle of the twentieth century, Muslim women focused their revolutionary struggle against colonial and missionary impositions and aimed to re-establish a national and religious identity (Gole 1996). So the initial focus of Muslim women's political engagement and public appearance was on mobilizing women's support for the nationalist struggle against the colonial powers, not necessarily for gaining their own rights independent of this struggle (Mohanty 1991; Helie-Lucas 1994a; Narayan and Harding 2000).

As the history and heritage of Muslim societies is radically different to Western development and culture, it is not surprising that the feminism which appeals to Muslim women, and which is perceived to be relevant to their society, is generally different to that developed by women in the West. In late eighteenth and nineteenth centuries the discourse of rights and citizenship was totally absent in most Muslim societies. In clear contrast with the East, Western feminism was a product of the rise of capitalism and the accompanying modernist culture and politics. In the twentieth century, Western women demanded equality in the public realm as well as in the private sphere of the household. Feminism, in terms of the western, liberal idea and politics of gender equality, reached Islamic societies in the late nineteenth century. Responses were diverse, ranging from a tentative interest in women's emancipation to its outright rejection (Abu-Lughod 1998: 331; Badran 1995). However it was obvious from the beginning that the debate was centered on the compatibility of the idea of the general emancipation of women with the principles of Islam.

During the first half of the twentieth century, Islamic societies changed due to the varying impacts of colonialism, modernism, nationalism and socialism. Conflicting cultural and political attitudes emerged, one effect being that upper and middle-class women demanded participation in public life in greater numbers than before by arguing for legal equality (Keddie 1992: 14). During this period, women's activism more generally began to surface. For example, in Iran, a tentative women's movement emerged during the Constitutional Revolution of Iran (1906-1911). In 1921 in Egypt, the first Egyptian women's nationalist demonstration was organization by Huda Shaarawi who became the president of a women's national organization, Wafdist-Women's Central Committee. In 1923 she also became a founder of the Egyptian Feminist Union (Badran 1993). Despite previous instances of individual and select groups of women participating in social and cultural activities, women now constituted a new social force asking for an overall redistribution of power both in public and private spheres, which was not comfortable for the Islamic groups, or secular forces and states.

Further developments during the mid 20th century occurred predominantly in Arab countries. The Arab Feminist Conference (1938) in Cairo and the International Alliance of Women's (IAW) Congress in Copenhagen (1939) gave a much needed impetus to 
Arab/Eastern women to pursue demands for equal rights in the family, the abolition of polygamy, compulsory education, the franchise for women and equal pay for equal work (Moghissi 1999: 130). Women's rights as citizens within a unitary Arab framework was also one of the main agendas discussed in the Congress with a view to the implementation of this aim in participants' respective countries (Badran 1995: 242). By the end of 1944 the efforts to consolidate a collective vision and strengthen feminist movements inside Arab countries coalesced and the Arab Feminist Congress was convened in Cairo. The Congress was twice the size of the 1938 meeting, with more middle-class professional women attending rather than only those from rich merchant and landowning families whose male family members had political affiliations with the state. Arab feminists took up the challenge of constructing citizenship in the postcolonial modern Arab states (Badran 1995: 239).

In 1945 an Arab Feminist Union (AFU) Confederation was established, comprised of feminist unions from several Arab countries. In 1952, in Egypt, the government's revolutionary measures against women activists (consisting of suppressing and co-opting their independent liberal movements under the state run machinery), resulted in serious damage to women's independent activism. Feminists like Zaynab al-Ghazali were imprisoned and one of her male role models, Sayyid Qutab, was executed. The patriarchal state authority banned the Egyptian Feminist Union (Badran 1993). Its name had to be changed to the Huda Sharawi Association and by 1958 its function was largely limited to social welfare activities. The fate of women's rights in other Arab countries with highly centralized state regimes was similar, and there was no space for an independent feminist movement. Consequently each national feminist union was incorporated into the state, mostly under the ministries of social welfare that dispensed government funding, and in this way governments controlled the agendas (Badran 1995: 250).

The incorporation of women's rights into government departments allowed governments in Egypt, Tunisia, Iraq and Jordan, to grant limited rights to women's organizations in part, so that they could no longer claim a need for widespread change. This strategy ultimately led to the dissolution of many groups. Gradually women's committees within nationalist and political parties split to form their own organizations due to disappointments in their male counterparts who reneged on many promises made, and also due to their growing awareness of a sense of separateness within the common aspirations which bound them (Darwiche 2001; Mojab 2001; Sullivan 1998; Toprak 1994). Women realized that their struggles and their demands for political and social rights were in constant conflict with national forces that excluded women from decisionmaking process. In some other countries, for example in Sudan, women participated in the national independence struggle in the mid-1950s. Similarly, in the Algerian Revolution, women participated from 1954-62 and later some organized feminist activity ensued. In Jordan, the first Jordanian Women's Union was established in 1945 under a 
royal decree. However, this Union remained restricted to the upper class and maintained a charitable mandate. Since 1947 the Palestinian women have increasingly asserted themselves as nationalists and feminists simultaneously (Badran and Cooke 1990: xxv). In Kuwait, a women's movement emerged in the late 1960s, and illustrates that where women are freer to express their attitudes on gender issues, feminism has gained the most visible public face (Hatem 1993: 35). This is not the case in Saudi Arabia where women are unable to gain such liberty as in every daily instance they are dependent on their male guardians (Doumato 1999).

The adoption of capitalist growth strategies by countries such as Turkey, Egypt and Iran created new challenges for the majority of Muslim women in the 1960's. They were forced to enter the paid work force; and subsequently it became clear that the capitalist transformation of the economy would have an uneven impact on women's lives. Upper and middle class women generally benefited from increased education and greater job opportunities, but the poor, both in rural and urban contexts, suffered due to the overall process of modernity. They concomitantly faced the psychological problems of adjustment to a society in transition, where prevailing traditions were in conflict with the economic pressures, which created anxiety and confusion. The men in these societies may superficially appear to accept the equality of the sexes but in practice they resist it (Rassam 1984), as was the case earlier in the twentieth century.

\section{The resurgence of feminism from the 1970's}

The United Nation's Decade for Women (1975-85) and the associated specific forums and meetings held world wide, increased pressure on all governments to address the issue of women's rights. The United Nations' emphasis on women's issues generated a myriad of official debates and an accompanying mushrooming of women's organizations within both Western and non-Western societies. In the 1970's Islamic governments initiated a trend of liberalizing or reexamining their dominant conservative position, for example in Sudan and Tunisia. These examinations led to the conclusion that the inclusion of women in all facets of the political process was consistent with Islam and that the conservative position of strict segregation was based on custom rather than the principles of Islam (Ghadbian 1995: 27). So in some Muslim countries women's rights were officially brought to the agendas of governments, although in most cases the governments' reactions consisted only of lip service to liberation policies (Haddad 1982: 54). At the end of the United Nation's Decade of Women (1975-1985), in the non-government forum in Nairobi, a large number of Arab feminists revived the earlier plan of pan-Arab feminism with the name of the Arab Women's Solidarity Association (AWSA). The Association attained the status of an International Arab organization and it was accepted as a consultative body in the Economic and Social Council of the United Nations (Badran and Cooke 1990: 366). 
To oppose the repressive regimes and the fundamentalist groups, after the 1970s, the emergence of non-government women's groups and organizations bloomed with postIslamist and post-modernist definitions and solutions to women's issues. The efforts of the United Nations' development agencies ${ }^{4}$ helped to stimulate interest in the needs of women and led to the establishment of groups around those needs (Hatem 1993). Along with the non-government organizations, the United Nation also worked through government agencies. There were a few organizations that embraced concepts that had been previously considered taboo, such as equality, empowerment or sustainable development with a feminist vision (Darwiche 2001: 19). These non-government organizations were critical of the state, as they claimed the governments did not go beyond the needs of literacy, vocational training, and family planning.

However the prominence of women's rights in Islamic countries was to be challenged by another movement providing change of a reactionary nature. Following the Islamic Revolution in Iran (1979), a religious revivalist mood in Muslim countries began to emerge. As women were often positively affected by the rapidly changing social and economic systems, they posed a major obstacle to re-Islamification policies in countries like Turkey, Sudan, Algeria, Tunisia and Iran. But many pro-Islamist women's groups emerged in these countries as well (Hatem 1993). In general it was an alarming situation for Muslim women, especially women from the middle and lower-middle classes, as the new reactionary state policies developed by religious leaders were intended to restrict women from public participation and confine them to the domain of private family life. The promulgation of discriminatory Islamic Laws, ordinances such as compulsory dress codes and the segregation of the sexes undermined women's newly found status. For the working woman, low paid jobs, harassment in the work place, a lack of job security, and increased male privilege created a generally repressive environment (Baden 1992: 3; Keddie 1992: 14).

The 1980s witnessed a new boom of activity in women's movements in reaction to the conservative trends. This was also in line with the international trends towards the enhancement of women's status, which favored considering women's rights as part of human rights. Consequently, a number of women's organizations emerged in Muslim societies, with programs related to social work and charities, but very few with any clear feminist agendas assimilating concepts of equality and empowerment. A few organizations dealt with concepts like sustainable development, comparative analysis of laws, violence against women and reproductive rights (Darwiche 1999). For example, in 1986 the Simorgh Association gathered together in Lahore, Pakistan, a group of women representing Muslim communities in Asia and the Arab world. Also in 1986, the 'Women Living Under Muslim Laws' network brought together Muslim women from within the Arab world, Africa and Asia and set down the basis if its first Plan of Action. Another conference in 1987 was held in Mumbai (Bombay), India, gathering several hundred women from various religious backgrounds, under the theme 'Women, Religion and 
Personal Laws'. And, since the Fourth World Conference on Women held in Beijing in 1995, not only have the numbers of women's organizations increased, but also they have adopted a much more aggressive line of action towards improving the status of women in Islamic countries.

To employ the term 'feminism' is still seen to be problematic in Islamic circles, thought to be both Western and alien ${ }^{5}$ (Gardezi 1994). According to Fernea (1998) in her book, In Search of Islamic Feminism, people in Muslim countries consider that feminism is a luxury indulged in by rich people, the elite, university graduates, politicians and novelists. Fernea, among others, argues that feminism is not concerned with women in the street, because the feminist struggle bears no relation to their struggle of making ends meet for food and the fight against sickness. So 'feminism' is used only by social science researchers and academics for convenience but is not a term that is used generally by women in common parlance.

Clearly, the context and nature of women's rights struggles have varied agendas between Islamic countries and has been differently evidenced in various historical contexts. Amid hopes and fears there is ongoing debate about the compatibility of Islam and feminism in the discourses emerging at the beginning of the 21 st century and feminists have attempted to make sense of the relationship between feminism and Islam.

\section{Feminism and Islam}

There is a widespread assumption that gender inequalities in Muslim countries are due solely to the influence of religion of Islam. However, increasing numbers of studies in the field have challenged this assumption. By looking at the historical and the cultural forces that give rise to the particularities of gender relations in given locales it is possible to move beyond such a reductive account of women and Islam (Cooper 1998: 22), especially in the context of the practice of purdah.

The concept 'Islamic feminism' emerged in the 1990's in the growing western and Muslim literature examining Muslim women's struggles in context of their culture and religion. The term 'Islamic feminism' brings together double commitments: i) to a position of faith and ii) to women's rights both inside the house and outside. An Islamist feminist ${ }^{6}$ does not have a fixed identity per se, but rather, creates a new, contingent subject position. This location confirms a sense of belonging to a religious community while simultaneously allowing for activism on behalf of, and with, other women. Islamist feminists link their religious, political, and gender identities so as to claim simultaneous and sometimes contradictory allegiances even as they resist globalization, local nationalisms, Islamization, and the patriarchal system that pervades them all. Moreover, the emerging feminism(s) in the Muslim world are complex, multi-layered and specific to each country and region, and vary from the situation of one demographic stratum of 
women to another (Maumoon 1999). Poston suggests that research and general observation indicate that the use of the term 'Islamic feminism' (like 'feminism') is increasing, while at the same time it is controversial (2001: 55-56). In spite of the continuing debate the concept is gaining popularity in the context of Islamic feminism as a discourse, a mode of analysis, and Islamic feminism as an identity.

The main concerns of Islamic feminists generally revolve around the question of communal morality linked to the status of women (Mojab 2001), and the development of a liberation theory for women within the Islamic religious framework. So adherence to Islam, femininity, familial responsibilities, complementary not competitive roles for males and females, and global identity of the Muslim community generally, all emerge as part of the dominant discourse of Islamic feminism. Islamic traditions dictate that any struggle, including the struggle for women's progress, is to be achieved in tandem with the wider struggle to improve the living conditions of the society as a whole. It is argued that while Muslim women may be committed to the feminist cause, there are certain religious and cultural traditions which may not be ignored (Al-Faruqi 2001). Some of these traditions include the extended family system, family participation in the contracting and preservation of marriage, an emphasis on the community as a whole instead of individualism, and the differentiation of sex roles that are beneficial for keeping a balance in the society.

Based in the U.S.A, the Pakistani feminist theologian Riffat Hassan (Helie-Lucas 1994a: 269-270) defines feminism as the philosophy which, while accepting the biological differences between the sexes, affirms their essential equality. Her interpretation of feminism is that women are equal to men and they ought to be able to exercise the fundamental human right to develop their physical, mental and spiritual potentialities in an environment in which patriarchal structures and systems of thought are eliminated. She argues that in the contemporary Muslim world, laws instituted in the name of Islam cannot be overturned by means of political action alone, but through the use of better religious argument and a progressive argument adapted to present circumstances (Hassan 2001). Furthermore she optimistically believes that, based on her definition, feminism embraces the same goal as Islam in aiming to create a just social order in the world. Thus feminism is compatible with Islam, as it furthers rather than frustrates the larger ends of Muslim women.

Traditionally in Islamic societies, gender roles are seen as complementary, and a distinction is drawn between the public and the private spheres, with women responsible for affairs within the house and men having the responsibility for activities outside the house. In the wake of modernity and movements such as feminism, this cultural and social traditionalism in relation to gender roles is challenged, as women are increasingly demanding that they take their place in public spheres. Islamic feminists strive to ease patriarchal pressures on women, making patriarchy less oppressive. This is certainly a 
feminist project, but one which falls short as it does not pose a serious challenge to patriarchy as an institution, which is recognized as being the root cause of gender disparity (Mojeb 2001: 130-131). Ali Bulac, a self-proclaimed Turkish feminist, critiques Islamic feminists, suggesting that, 'Patriarchal oppression is a phenomenon existing in every society...It is just a big lie that women are not devalued in this region...Feminism invites women to rebel against the domination of men, [i]n the house, at work, in the street'. She further asks, 'Is it not possible to leave oppressive attitudes instead of insisting to play \{sic\} the words? We must accept that it is really difficult to give up habits, which are so enjoyable' (quoted in Gole 1996: 123).

The above concern seems founded on one discourse of Muslim feminism, which argues that Muslim women were already granted rights in the 7 th century when the religion of Islam dawned, therefore women's rights have long been a part of Islamic culture. According to the Quran (the Holy Book of Muslims) and the Sharia (Islamic Law) women are equal to men and they have legal and property rights just as men ${ }^{8}{ }^{8}$ However this view is not unproblematic, as one finds various fundamentalist interpretations by different scholars, problematic. Furthermore, claims that Islam provides a complete code of life giving details of the relationship between a man and a woman, is discrepant with research that finds great disparities between theory and practice in the very nature of women's lives in Islamic societies (Ali 2000; Merniss1987; Rozario 1996; Poya 1999).

Clearly there is a difference between the claimed and the written word, and what is being practiced in Muslim countries (Keddie and Beck 1978). There is an ongoing debate about women's status and rights and their compatibility or non-compatibility with Sharia among both secularists and conservatives in many Middle Eastern, South Asian and African societies (Saadawi 1980). Muslim laws as they exist in the real world today result from the combination of interpretations of the holy text entwined with local traditions. It is important to realize that traditions and cultural practices, which flourish under the name of the Islamic religion, are justified by religious fundamentalists and imposed on women. Examples are oral divorce which is legal in India (Hoodfar 1998), Bangladeh (Sobhan 1994; Shehabuddin 1999) and Pakistan (Ali and Naz 1998), female circumcision in Sudan, Somalia and Egypt (Kassamali 1998), stoning as a punishment for adultery, and requirement of eyewitnesses as proof of rape in Pakistan and Iran (Ali 2000; Hoodfar 1998). Equally the tradition of seclusion in the Middle East and West Africa (Bodman and Tohidi 1998) and women not being allowed by law to drive in Saudi Arabia (Doumato 1999) are all practices that are culturally specific to these regions but believed to be Islamic and are therefore presented as such (Hele-Lucas 1994: 395). In Muslim countries the state also politicizes issues in the name of religion: for example there is a diversity of Islamic opinion in regard to the use of contraceptives and abortion. These practices are legal in Tunisia (Charrad 1998), enforced in Bangladesh (Siddiqi 1998), whereas in Pakistan abortion is forbidden whilst contraception is allowed, while in 
Algeria both are forbidden (Dubey 1998; Kandiyoti 1991). Clearly there is not one 'Islamic' position on these cultural practices.

The nature of gender inequalities in Muslim societies calls for a struggle by Muslim men as well as women to gain women's rights. However, in reality it is more incumbent on women to challenge situations where there is discrimination in laws and their practice, which affect women's lives in many ways. Areas open to challenge include legal and political status of women, property rights, the institution of polygamy, violence against women, conflicting mandatory and Sharia laws (which are further confused by patriarchy). This list is not exhaustive and can be elaborated if we look into the indigenous cultures of each Muslim country. Research in Iran, Turkey, Morocco and Egypt shows that political exploitation of religion is obvious in history and religion is flexible sometimes to the point of being manipulated by those who are in power (Sadawi 1986: 249). Al Faruqi also endorses the view that for Muslim women, the source of difficulties experienced is not necessarily Islam and its traditions, but certain ideological institutions in societies, ignorance and distortion of the true Islam and its exploitation by individuals in power (Al Faruqi 23/4/2001). Religious functionaries throughout Muslim history have closely worked with the ruling elite, and rulers have used them to legitimize their decision and governance (Hussain 1984: 5). Equally, the new wave of Islamic resurgence in many Muslim countries provides a chance for religious leaders to gain political power and influence (MacEION and Shahi 1983: 6).

In Muslim countries the debate regarding feminism revolves around the tensions between women's traditional roles and society's adjustment to change and acceptance of new roles for women (Rozario 1998). Moreover, increasing Islamic fundamentalism and the notion that Islam, and by implication the 'community', is undermined by feminism, impacts on the acceptability of women's movements as well. Muslim feminists, prior to addressing their key demands, have to demonstrate that they are truly rooted in their religion and culture so as to distinguish themselves from Western feminists (Hele-Lucas 1994). To strengthen their legitimacy and stop accusations that they are 'Westernized', Muslim women are devoting time to researching their own feminist history, which is imperative for the continuation of their cause.

However, it is apparent that there is not one essential Islamic feminism but rather a number of theoretically, conceptually different groupings, which will be examined in the next section of this chapter.

\section{Diverse nature of feminism in Muslim countries}

Different historical, political and social trajectories in Muslim countries challenge the idea of a single prevailing feminism that is Islamic. There is a large portion of women's rights activists who believe that feminism is only viable within an Islamic framework, as 
only then is it a culturally sound and effective strategy. This feminist position derives from an essentialist Islamist discourse that posits Muslim women's identities as fixed and their social position as necessarily subordinate to men (Moghadam 2002b; Siregar 1998). A closer look into this 'Islamist' women's rights movement shows that the women from this philosophical/religious position opt to work for complementary sex roles rather than challenging cultural conservatism, thus distancing themselves from Western women's claim on feminism (El Guindi 1996: 159-61 cited in Moghassi 1999: 134). Yet they still join mainstream feminists' quest for equality, albeit differently, arguing for the need to achieve a balanced gender complementarily which asserts their right to a different understanding of freedom and liberty (Afsher and Maynard 2000: 811). Further investigation of Islamist feminists reveals a spectrum of positions such as liberals, radicals and conservatives. Each type exhibits a degree of diversity, flexibility and development in their position on women, which is context and issue bound, and may occur at the same time in the same country with parallel struggles in each socio-economic category (Darwiche 2001).

Another philosophical position adopted by Islamic feminists is that they, as a matter of political advantage, construct a theological basis of Islam to carve their own path to freedom. This is another example which demonstrates Muslim feminism is not necessarily anchored under single banner feminism (Mojab 2001). There are collaborations and political alliances across diverse discourses. These women anchor their belief in the discourse of Islam with the Quran as its central text and exegesis as its main methodology (Badran 2000) to find solutions for women's oppression. They consider their advocacy for women's rights to be an Islamic project involving a womencentered reading of the Quranic texts or 'scholarship-activism'8 (Badran 2002: 2).

Feminism in Muslim countries is growing on the basis of the indigenous needs of the individual countries, which are at different stages of religious revivalism on the one hand, and political, economic, cultural and social complexities on the other. But there are many common features of women's movements in postmodern Muslim countries (Tucker 1993: ix; Hatem 1993: 29- 47). Feminism has influenced not only the political and intellectual discourse but has also challenged academia and academic thinking as is shown by the proliferation of articles and books on issues related to women (Afshar and Maynard 2000). The following discussion will define and expand, across the board at different levels, on the emerging contours of feminism(s) in Muslim countries.

Liberal Islamist feminists seek equal rights in the public sphere but complementary rights in the private sphere, by challenging the conventional notion of male authority over females in areas such as marriage, family, and inheritance. Liberal Islamist feminists promote the right of women to work outside the home, which necessarily involves the mixing of sexes. In relation to the public sphere, Islamist feminists argue for a greater social role for women and full participation in the political process as well as women's 
right to apply for any public office, such that women may be a Qazi (judge) of an Islamic court or Head of a state (Badran 2000; Mojab 2001). Islamist women are adopting Islamic dress as a tool of women's empowerment and as a liberating factor offering chances of mobility in the public sphere, relieving women from the burden of sexuality, and protecting women from male harassment.

Revolutionary and nationalist women in Iran, Turkey, Sudan and Algeria continue their struggle against marginalization and exploitation by Islamic governments. These feminists operate within different paradigms by creating an Islamic discourse around their right to freedom, rather than borrowing from Western feminism. They pursue national identity, association with the traditional culture, and see themselves as the guardians of national culture, indigenous religion and family traditions. Mernissi gives a Moroccan instance of a feminist assessment of nationalism, arguing that the accelerated participation of women in the process of modernization is actually what facilitated the turn to Islamic tradition (1991: 153-154). In Central Asia women are caught between decolonization, nationalism, Islamism and images of emancipation in the industrialized society. Feminist discourses are at the crossroads of Islam and cultural identity, and are grappling with a re-evaluation of Islam gender interests and feminine identity (Michaels 1998: 199).

Muslim women living in diaspora ${ }^{10}$ have played an active role in the revival of the Islamic religion. Numerous Muslim women's organizations have emerged around the world, which specifically deal with research related to women issues. Moreover, diasporic feminist academics and researchers of Muslim background living and working in the West coined the term 'Islamic feminism'. The increasing feminization of Islam, despite the emphasis on traditional gender roles, has resulted in demands for women's access to positions of religious leadership (Maumoon: 1999). For Muslim women living in the USA, Britain, Canada and elsewhere, the hijab clad women act as a powerful symbol of religious identity and conformity with their Islamic community (Maumoon: 1999). This has occurred to such an extent that in many European countries the State took a legal stance to denounce the right of Muslim schoolgirls to wear hijab (Goodwin 1994: 30; Dawn 2002; SBS News 2002). Islamist feminists (both liberal and radical) living in diaspora are spearheading revision of the ossified interpretations of Islam and undertaking scriptural commentary by nurturing a critical view of the Islamic way of life, especially in relation to issues that are important to women (Abugideiri: 2001).

Radical Islamist feminists discourse also cleaves from a traditional religious framework want a gender reconfiguration from within Islam, by challenging the Quranic interpretations and the reliability of Hadith. Using religious texts as their foundation, they want to develop a feminist perspective on the notion of equality between the sexes. They intend to shun religious extremism so as to bridge the ideological divide between feminists. Radical feminists are playing an important role in raising feminist 
consciousness by differentiating between God and its clergy, between theology and politics. The second and third generations of younger Islamist women are more revolutionary, but the majority has ambiguous and even contradictory ideas of the technicalities enshrined in secular and Islamic Law (Maumoon 1999; Ahmed 1992). The radicals do not have many qualms about the cultural aspect of purdah practices. Thus they do not take literally the religious message to restrict their dress code but concentrate instead on human dignity and how both sexes conduct themselves in public space (Hatem 1993).

Conservative Islamist feminists operate explicitly within a religious framework and argue that woman's oppression stems from a misguided attempt to trespass on the territory of men. They believe that women are equal but different, physiologically and psychologically. They consider segregation necessary to control and inhibit sexual urges. They also believe that women have to be dependent on men for their livelihood and thus this category of women activists choose for themselves the role of domesticity and motherhood. They see men and women as performing different but necessarily complementary roles (Waines 1995; Moghissi 1999). A just society, they argue, is a society that strives to promote recognition and compatibility between the sexes rather than competition between them. They campaign for sexually segregated educational institutions, businesses and hospitals.

The conservative Islamist women's groups in Turkey, Iran and Pakistan try to counter the efforts of the liberal feminist groups. In Turkey there are independent groups working against a more liberal state. But countries such as in Iran and Pakistan the secular and left oriented groups the state creates and provides funds and many benefits to conservative women groups and their families to challenge and counter (Helie-Lucas 1994a: 271-272). Within this conservative grouping there are individuals and groups who reject the existing secular laws in favor of the total application of Islamic laws. Conservative Islamists always refer to religious authority in their political and social agenda. They also consider working women as a threat to the morality and productivity of the society. They argue that men and women alike are oppressed, since the state is run without regard to their interpretation of Islam and has succumbed instead to dominant, secular, Western ideology. However, even within the conservatives feminists there are some who are studying for higher qualifications and seeking employment opportunities, even in desegregated institutions, and who are against state generated discriminatory laws and violence against women. This can occur because, as Maumoon (1999) argues, in the last decade or so the animosity and strict demarcation between various Islamist feminists' discourses is blurring and a new configuration is emerging on the basis of constraints placed on women. The conservative Islamists consider that their role in the fundamentalist movements is irreversible and has contributed to the social advancement of women (Afshar 1994). 
Besides the religious discourses of feminism that have already been discussed, there are other feminist groups with a secular paradigm. They encompass a variety of perspectives in advancing women's rights but do not sacrifice their culture or nationality identity. Secular feminists position their activities outside of the religious domain and appeal instead to concepts such as internationally recognized standards of human rights. They argue for legal reforms and the necessity for the greater education of women. They have little in common with Islamist feminists. They believe Islamic law is already enshrined in the state laws, and consider both to reflect Islam. Therefore they call for explicit repudiation of religious ideas from the legal framework and for the separation of politics from religion and for the separation of religion from the state (Povey 2001: 55). They argue that hostility towards feminist demands is inherent in the fundamentalist notion of divine laws, and therefore in Islamic societies women's liberation may involve deIslamization of every aspect of life (Kandiyoti quoted in Mojab 2001: 131). Without renouncing their cultural identities, nationalities and even religion, secular feminists believe that human rights are universal and should not have any cultural boundaries (Helie-Lucas 1994b). By promoting international conventions, secular feminists cut themselves off from the immediate political and social context, and thus risks being labelled as irrelevant by other feminist groups as Islam is absent from their arguments. In reality, activists who do not adopt an Islamist discourse are accorded little credibility in 'Islamic feminist' circles.

\section{End Notes}

${ }^{1}$ An extensive analysis of the discourse of Western feminism is beyond the scope of this treatise. Therefore it will not be dealt with as such, but will be discussed only in the context of exploring feminism in Muslim countries.

2 Arab countries stretch from Morocco in the West to Iraq and the Arabian Peninsula in the East as described in Badran and Cooke (1990).

3 According to Amal Rassam, (1984: 5) 'harem' means 'sacred' or 'women of the house', but it is ironic that its popular meaning is virtually the opposite of its original meaning, referring to concubines.

${ }^{4}$ Such as the United Nations Development Program (UNDP), the International Fund for Agricultural Development (IFAD), and last, the UNESCO Expert Meeting on Multidisciplinary Research on Women in Arab World.

5 For example, in early 1990's a Women's Action Forum member in Islamabad told Fauzia Gardezi (1994) that they would prefer not to be called feminists. In 2000 the present writer while interviewing a few WAF members noticed that they still do not use this term. 
${ }^{6}$ Karam (1998) argues that within Muslim societies besides the secular feminists there are two other versions of feminists': the Islamists and the Muslim. The present writer argues that Islam is the religion and the believers of this religion are Muslims. So the women rights activists can either be categorized as Islamist feminists or Muslim feminists but not two different categories.

${ }^{7}$ Will and Inheritance references from Holy Quran are: Surah Al-Baqra (2) verses 180182. Surah Al-Nissa (4) verses 7,11-12,176. Regarding gender parity Surah Al-Nissa (4) verse 32, 124. Surah Al-A'raf (7) verses 26-31. Surah Al-Nur (24) verse 26. Surah Al-Ahzab (33) verses 35-36,58,73. And many more references are there in the text.

${ }^{8}$ Reference quoted in Badran (12 November 2002) from 2001 book Windows of Faith by Gisela Webb.

${ }^{10}$ For individuals living in diaspora religious revivalism connects them with the origins of Islam and to re-enacting the event of migration of the Prophet (from Mecca to Medina) to new lands for invitation to Islam.

\section{References}

Abu-Lughod, Lila. (1998) Remaking Women: Feminism and Modernity in Middle East. New Jersey: Princeton University Press.

Afshar, Haleh and Maynard, Mary. (2000) 'Gender and ethnicity at the millennium: from margin to centre', pp. 805- 819 in Ethic and Racial Studies. Vol. 23. Number 5 September. 2000 Routledge Journals, Taylor \& Francis Ltd.

Ahmed, Laila. (1992) Women and Gender in Islam: Historical Roots of a Modern Debate. New Haven: Yale University Press.

Al Faruqi, Lois L. (2001) 'Islamic Traditions and the Feminist Movement', pp. 1- 11. http://www.islam101.com/women/feminism. (23/4/01)

Ali, Shaheen Sardar \& Naz, Rukhshanda. (1998) 'Marriage, Dower and Divorce: Superior Courts and Case Laws in Pakistan', pp. 107- 141 in Shaheed, F. Warraich, S.A. Balchin, C. and Gazdar, A. (eds.) Shaping Women's Lives. Lahore: Shirkat Gah.

Ali, Shaheen Sarder. (2000) Gender and Human Rights in Islam and International Law. The Hague: Kluwer Law International.

Amin, Qasim. (1992) The Liberation of Women. (Translated by Samiha Sidhom Perterson). Cairo: The American University, Cairo Press. 
Baden, Sally. (1992) The Position of Women in Islamic Countries. Brighton: Bridge, Development-Gender Institute of Development Studies. http://www.ids.ac.uk/bridge.htm. (April 2000).

Badran, Margot and Cooke, Miriam. (1990) Opening the Gates: A Century of Arab Feminist Writing. Bloomington: Indiana University Press.

Badran, Margot. (1993) 'Independent Women: More Than a Century of Feminism in Egypt', pp. 129- 147 in Tucker, Judith E. (ed.) Arab Women: Old Boundaries, New Frontiers. Indiana: Indiana University Press.

Badran, Margot. (1995) Feminists, Islam and Nations: Gender and the Making of Modern Egypt. Princeton: Princeton University Press.

Badran, Margot. (2002) 'Islamic feminism: what's in a name?' Al-Ahram Weekly Online, Issue no. 569, pp. 17- 23. Cairo.

Badran, Margot. (2002) Exploring Islamic Feminism. pp. 1- 2. Georgetown: Woodrow Wilson, International Center for Scholars, Georgetown University.

Charrad M. M. (1998) 'Cultural Diversity Within Islam: Veils and Laws in Tunisia', pp. 63- 78 in Bodman H.L. and Tohidi, Nayereh (eds.) Women in Muslim Societies: Diversity within Unity. Colorado: Lynne Rienner Publishers.

Cooke, Mariam. (2001) Women Claim Islam: Creating Islamic Feminsm through Literature. London: Routledge.

Darwiche, Nawla. (2001) 'Women in Arab NGOs', pp. 15- 20 in Feminist Review, No. 69, Winter 2001. http://www.tandf.co.uk/journals

Doumato, Eleanor Abdella. (1999). 'Women and Work in Saudi Arabia: How Flexible are Islamic Margins?’ pp. 568- 583. Middle East Journal, V. 1, 53, No. 4 Autumn 1994.

El Guindi, Fadwa, (1999) Veil: Modesty, Privacy and Resistance. Oxford: Berg Publishers.

Fernea, Elizabeth W. (1998) In Search of Islamic Feminism: One Woman's Global Journey. (And book review by Joe Sterling). New York: Doubleday. http://www.cnn.com/books/reviews/9806/11/islamic.feminism.cnn/ (7.06.01). 
Gardezi, Fauziz. (1994) 'Islam, Feminism and the women's movement in Pakistan: 198191', pp. 51- 57 in Bhasin, Kamla, R. Menon and Nighat Said Khan. (eds.) Against All Odds. New Delhi: ISIS International, Kali for Women and SAWF.

Ghadbian, Najib. (1995) 'Islamist and Women in the Arab World: From Reaction to Reform?' in The American Journal of Islamic Social Sciences. Vol.12, n.1, Spring 1995. Washington, DC: The Association of Muslim Social Scientists and The International Institute of Islamic Thought.

Gole, Nilufer. (1996) The Forbidden Modern: Civilizing and Veil. Michigan: The University of Michigan Press.

Haddad, Yvonne Yazbeck. (1982) 'The Case of the Feminist Movement'. pp. 54 - 70, In Contemporary Islam and the Challenge of History. Albany: State University of New York Press.

Helie-Lucas, Marie-Aimee. (1994a) 'Strategies of Women and Women's Movements in the Muslim World vis-à-vis Fundamentalism: From Entryism to Internationalism', pp. 251- 275 in Mendelsohn, Oliver and Baxi, Upendra. (eds.) The Rights of Subordinated Peoples. Delhi: Oxford University Press.

Helie-Lucas, Marie-Aimee. (1994b) 'Women in Muslim Personal Law', pp. 391- 407 in Moghadam, Valentine M. (ed.) Identity Politics and Women. San Francisco: Westview Press.

Hoodfar, Homa. (1993) 'The Veil in Their Minds and On Our Heads: The Persistence of Colonial Images of Muslim Women', pp. 2- 12 in Resources of Feminist Research, Vol. 22, Nos. 3 \& 4.

Hoodfar, Homa. (1998) Muslim women on the Threshold of the Twenty-First Ccentury. Dossier 21, September 1998. Network Women Living Under Muslim Laws.

Kandiyoti, Deniz. (1996) 'Islam and Feminism: a misplaced polarity', pp. 10- 13 in Women Against Fundamentalism (WAF Articles) Journal no. 8. http://www.gn.apc.org/waf/articles.htm. (4/3/01).

Karam, Azza. (1998) Women, Islamisms and the State: Contemporary Feminisms in Egypt. New York: St. Martin Press.

Kassamali, Noor J. (1998) 'When Modernity Confronts Traditional Practice: Female Genital Cutting in North Africa', pp. 39- 62 in Bodman H.L. and Tohidi, Nayereh (eds.) Women in Muslim Societies: Diversity within Unity. Colorado: Lynne Rienner Publishers. 
Keddie, N R. and Beck, L. (1978) (eds.) Women in the Muslim World. London: Harvard University Press.

Keddie, Nikki R. (1992) 'Introduction: Deciphering Middle Eastern Women's History', pp. 1- 22 in Keddie, Nikki R. and Baron, Beth (eds.) Women in Middle Eastern History: Shifting Boundaries in Sex and Gender. New Haven: Yale University Press.

MacEION, Denis and Al-Shahi, Ahamed. (eds.) (1983) Islam in the Muslim World. New York: St. Martin's Press.

Majid, Anour. (1998) The Politics of Feminism in Islam. Sign. Journal of Women in Culture and Society. Chicago, winter. http://global.uni.com/pqdweb. (13.3.01).

Marsot, Afaf Lutfi al-Sayyid. (1996a) 'Entrepreneurial Women in Egypt', pp. 19- 39 in (ed.) Mia Yamani, Feminism and Islam: Legal and Literary Perspectives. New York: New York University Press.

Maumoon, Dunya. (1999) 'Islamism and Gender Activism: Muslim Women's quest for autonomy', pp. 269- 283. Journal of Muslim Minority Affairs, vol. 19. Issue 2 October 1999, Abingdon. http://proquest.umi.com/pqdlink. (6/8/01).

Mernissi, F. (1987) Beyond the Veil: Male-Female Dynamics in Modern Muslim Society. London: Al Saqi Books.

Mies, Maria. (1986) 'What is Feminism?' pp. 6- 44 in Mies, Maria. Patriarchy and Accumulation on a World Scale. London: Zed Books Ltd.

Minai, Naila. (1981) Women in Islam: Tradition and Transition in the Middle East. New York: Seaview Books.

Moghadam, Valentine M. (2002) 'Islamic Feminism and its discontents: towards a resolution of the debate, pp.1- 20 in Sign, Journal of Women in Culture and Society, Summer 2002, v27, i4, p. 1135. University of Chicago Press. http://web2.infotrac.galegroup.com/itw/infomark/. (6/01/2003)

Moghadam,Valentine M. (ed.) (1994a) Identity Politics and Women: Cultural Reassertions and Feminisms in International Perspective. San Francisco: Westview Press.

Moghadam,Valentine M. (ed.) (1994b) Gender and National Identity. Helsinki: United Nations University/ World Institute of Development Economics Research. 
Moghissi, Haideh. (1999) Feminism and Islamic Fundamentalism. London: Zed Books.

Mohanty, Chandra Talpade. (1991) 'Under Western Eyes: Feminist Scholarship and Colonial Discourses', pp. 51- 80 in Mohanty, C. T. et.al. (eds.) Third World Women and the Politics of Feminism. Bloomington and Indianapolis: Indiana University Press.

Mojab, Shahrzad. (2001) 'Theorizing the Politics of 'Islamic Feminism', pp.124 -146 in Feminist Review No. 69, winter, online http://www.tandf.co.uk/journals.

Narayan, Uma. and Harding, Sandra. (2000) (eds) Decentering the Center: Philosophy for a Multicultural, Postcolonial, and Feminist World. Bloomington: Indiana University Press.

Okin, Susan Moller. (2000) 'Feminism, women's Human Rights, and Cultural Differences', pp. 26- 46 in Narayan, Uma and Harding, Sandra. (eds.) Decentering the Center: Philosophy for a Multicultural, Postcolonial, and Feminist World. Bloomington: Indiana University Press.

Petry, Carl F. (1992) 'Class Solidarity versus Gender Gain: Women as Custodians of Property in Later Medieval Egypt', pp. 122-142 in Keddie, Nikki R. and Baron, Beth (eds.) Women in Middle Eastern History: Shifting Boundaries in Sex and Gender. New Haven: Yale University Press.

Poston, Larry. (2001) 'Femininity Verses Feminism: Contemporary Islamic Perspectives on the Essence of Womanhood', pp. 47-62. American Journal of Islamic Social Sciences. V 18, n 4.

Poya, Maryam. (1999) Women, Work and Islamism. London: Zed Books.

Quataert, Donald. (1992) 'Ottoman Women, Households, and Textile Manufacturing, 1800- 1914', pp. 161- 176 in Keddie, Nikki R. and Baron, Beth (eds.) Women in Middle Eastern History: Shifting Boundaries in Sex and Gender. New Haven: Yale University Press.

Rassam, Amal. (1984) 'Introduction: Arab Women: the Status of Research in the Social Sciences and the Status of Women', pp. 1- 13 in Women in the Arab World. London: Frances Publishers.

Roded, Ruth. (2001) 'Mainstreaming Middle East Gender Research: Promise or Pitfall?', pp. 15- 23, in Middle Eastern Studies Association Bulletin. v. 35, n.1. Summer 2001. U.S.A. 
Rozario, Santi. (1996) 'Community and Resistance: Muslim women in contemporary societies', pp. 209- 223 in Summerfield, Penny et.al. (eds.) Women, Power and Resistance. Buckingham: Open University Press.

Saadawi, Nawal al. (1980) The Hidden Face of Eve. London: Zed Books.

Saadawi, Nawal al. (1986) 'Toward Women's Power, Nationality and Internationally', pp. 247- 257 in Diana L. Eck and Deraki Jain (ed.) Speaking of Faith. New Delhi: Kali for Women.

Shehabuddin, Elora. (1999) 'Contesting the illicit: Gender and the politics of Fatwas in Bangladesh', pp. 1011- 1044. Signs: Journal of Women in Culture and Society. Vol. 24, Summer 4 . Chicago. http://global.umi.com

Siregar, Wahidah Zein Br. (1998) 'Feminism in Indonesia: A Movement between the West and the Muslim Society', pp. 1- 11 in online Jurnal Studi Indonesia, vol. 8.2 (IAIN Sunan Ampel Surabaya).

Sobhan, Salma. (1994) 'National Identity, fundamentalism and the women's movement in Bangladesh', pp. 63- 80 in (ed.) by Moghadam, V.M. Gender and National Identity. Helsinki: The United Nations University.

Toprak, Binnaz. (1994) 'Women and Fundamentalism: The Case of Turkey', pp. 293306 in Moghadam, Valentine M. (ed.) Identity Politics and Women. San Francisco: Westview Press.

Treacher Amal and Shukrallah Hala, (2001) 'The Realm of the Possible: Middle Eastern Women in Political and Social Spaces', pp. 4- 14 in Feminist Review, No.69, winter 2001. http://www.tandf.co.uk/journals

Tucker, Judith E. (1985) Women in nineteenth-century Egypt. Cambridge: Cambridge University Press.

Tucker, Judith E. (1993) (ed.) Arab Women: Old Boundaries, New Frontiers. Washington D.C: Indiana University Press.

Tuttle, Lisa. (1987) Encyclopedia of Feminism. London: Arrow Books.

Dr. Riffat Haque is head of Women's Studies Department, Allama Iqbal Open University, Islamabad, Pakistan. Her areas of interest are: Women and Gender Studies, Development, Women and Islam, Gender and Environment, Distant and Non formal Education. 